\title{
Design of a chimaeric antigen and its use in the detection of lgG antibodies against rubella virus
}

Wenyue Xing ${ }^{1,2 \dagger}$, $\mathrm{Li} \mathrm{Li}^{1 \dagger}$, Jingnan Zhang ${ }^{1}$, Chunli Ma ${ }^{1}$, Xin Xue ${ }^{1}$, Shumei Ye ${ }^{1}$, Huiting Xue ${ }^{1}$, Ruiping Hu*, Yanhua Ma ${ }^{1,3^{*}}$ (C) and Hong Yuan ${ }^{1^{*}}$

\begin{abstract}
Background: Rubella virus (RV) is the causative agent of rubella or German measles. Although most infections cause only mild self-limited measles-like illness, the infection in pregnant women can cause severe foetal malformation or even miscarriage, especially in the first 3 months of pregnancy. Therefore, it is of great practical significance to establish a simple and sensitive RV detection method.

Methods: The partial epitopes of the E1 and E2 proteins from Rubella Virus were selected as the target sites, the sequence of the selected antigenic sites of the E1 and E2 were linked by a linker. The expression plasmid P6T was constructed by inserting the gene into PET-32A + with a histidine Tag. The P6 protein was induced and expressed in Escherichia coli L21 (DE3) and purified by nickel column affinity. The protein P6 antigen was identified by Western blotting analysis, and an anti-P6 antibody ELISA was established to test known serum samples to evaluate the capability of this method.

Results: After purification, the concentration and purity of the protein P6 were $0.283 \mathrm{mg} / \mathrm{mL}$ and more than $80 \%$, respectively. Western blotting analysis showed that the protein P6 could react with rubella virus positive serum. By ELISA, 36 negative sera and 58 positive sera were detected. The coincidence rate, specificity and sensitivity of the ELISA were $86.2 \%, 88.89 \%$ and $84.48 \%$, respectively. The P6 ELISA with a kappa coefficient of $0.715, P<0.05$, indicated excellent consistency.
\end{abstract}

Conclusions: The protein P6 with excellent antigenicity obtained from prokaryotic expression followed by chromatography purification could prove useful for early diagnosis of RV infection.

Keywords: Rubella virus, Prokaryotic expression, Serological diagnosis, Chromatography purification

\section{Background}

Rubella virus (RV) is the causative agent of rubella or German measles [1]. Although most infections cause only mild self-limited measles-like illness, the infection

\footnotetext{
*Correspondence: 783674348@qq.com; MYH5203756@mail.imu.edu.cn; 20080292@immu.edu.cn

†Wenyue Xing and Li Li contributed equally to this work

${ }^{1}$ College of Basic Medicine, Inner Mongolia Medical University, Hohhot 010110, Inner Mongolia, China

Full list of author information is available at the end of the article
}

in pregnant women can cause severe foetal malformation or even miscarriage, especially in the first 3 months of pregnancy $[2,3]$. Therefore, it is of great practical significance to establish a simple and sensitive RV detection method. After Rubella virus infection, IgM appears earlier than IgG. However, it is maintained for a short period of time and decreases in expression after 1 month until it turns negative. IgG antibody appears after IgM, and the level of IgG antibody shows a rising trend. The peak IgG expression appears 1-2 months after infection. Its original author(s) and the source, provide a link to the Creative Commons licence, and indicate if changes were made. The images or other third party material in this article are included in the article's Creative Commons licence, unless indicated otherwise in a credit line to the material. If material is not included in the article's Creative Commons licence and your intended use is not permitted by statutory regulation or exceeds the permitted use, you will need to obtain permission directly from the copyright holder. To view a copy of this licence, visit http://creativecommons.org/licenses/by/4.0/. The Creative Commons Public Domain Dedication waiver (http://creativeco mmons.org/publicdomain/zero/1.0/) applies to the data made available in this article, unless otherwise stated in a credit line to the data. 
level decreases very slowly. IgG can remain in the body for long periods of time, even up to a few decades [4-6]. Therefore, IgM can be used as a marker for early pathogen infection, and IgG antibody can be used as a marker for late infection and after infection.

RV has three structural proteins: one capsid protein (C) and two envelope proteins (E2 and E1). C is rich in arginine and proline residues, which make it positively charged and facilitate its reaction with genomic RNA during nucleocapsid formation [7]. As type I membrane proteins, E1 and E2 are heterodimerized to form complexes on the surface of the virus [8]. The main function of the spinous process complex is to collect host cell receptors and to mediate the fusion between the virus and host cell membrane [9]. For RV IgG antibodies, E1 has the most epitopes compared to $\mathrm{E} 2$ and $\mathrm{C}$ protein [10]. It has been found that a protein expressed by serially linking different epitopes of the virus can be used for the detection of RV-specific IgG with good diagnostic efficacy [11]. In this paper, the immunodominant regions of two RV structural proteins were expressed in tandem on the same protein, and the recombinant protein was applied to an indirect ELISA for detecting RV-IgG.

\section{Methods}

\section{Materials and reagents}

Escherichia coli (E. coli) DH5 $\alpha$ competent cells were obtained from our own laboratory. BL21 (DE3) competent cells was purchased from TransGen Biotech(China). T4 DNA ligase and all restriction enzymes were purchased from NEB. HRP-labelled goat anti-human IgG was purchased from Santa Cruz (USA). DAB (USA, Vector labs). Samples from 94 umbilical cord serum samples collected in 2014 from HuNan Province by the Chinese Center for Disease Control and Prevention. The origin of samplesis from individuals with history of $2 \mathrm{~B}$ genotype infection. All of them were confirmed by a RV ELISA Kit (Germany, VirionSerion), of which 58 were positive and 36 were negative.

\section{Construction of the expression plasmid P6T}

Based on references [12-14], sequences with antigenic sites of E1 (199-286) and E2 (1-115) were selected, they were linked by a linker (GGGGSGGGGSGGGGS). After codon optimization, restriction endonuclease sites for BamHI and HindIII were added at both ends. The construct was then synthetized by the Invitrogen company (named P6T). P6T (18 ng/ $\mu \mathrm{L})$ was digested by BamHI and HindIII. P6T was purified and ligated to the pGEM$\mathrm{T}$ expression vector. Then, the plasmid pGEM-T-P6T was transformed into E. coli DH5 $\alpha$. The positive clones were further identified with the restriction endonuclease digestion of BamHI and HindIII. The sequence was confirmed by SinoGenoMax Company.

\section{Preparation of the protein P6}

Plasmid P6T was transformed to BL21 (DE3) competent cells. The transformed BL21 (DE3) was inoculated in LB medium containing $50 \mu \mathrm{g} / \mathrm{mL}$ ampicillin and induced expression. After cleaning twice with $10 \mathrm{~mL}$ high salt lysate $(20 \mathrm{mM}$ Tris, $0.5 \mathrm{~m} \mathrm{NaCl}, 2 \mathrm{mM}$ EDTA, $5 \%$ glycerol, $0.5 \%$ TritonX-100, PH8.0), ice water bath ultrasound $(270 \mathrm{~W}$, ultrasound $5 \mathrm{~S}$, pause $25 \mathrm{~S}$ ) for $15 \mathrm{~min}$. After centrifugation, the precipitate was dissolved in $10 \mathrm{~mL}$ equilibrium buffer solution (20 mM Tris, $0.5 \mathrm{~m} \mathrm{NaCl}, 10 \mathrm{mM}$ imidazole, PH8.0), and centrifuged again. The resulting supernatant was filtered by a 0.45 um filter. The filtrated supernatant was purified by nickel column and eluted with gradient elution of $60 \mathrm{mmol} / \mathrm{L}$ and $300 \mathrm{mmol} / \mathrm{L} \mathrm{imi-}$ dazole. The elution samples were analyzed by SDS-PAGE and the content and distribution of the target protein were observed [15]. The eluent with higher purity was desalted by dialysis, the target protein was concentrated by ultrafiltration centrifuge, and stored at $4{ }^{\circ} \mathrm{C}$ for later use.

\section{Western blotting analysis of the protein P6}

Protein P6 was separated using 10\% SDS-PAGE and transferred to PVDF membranes. The membranes were blocked with $5 \%$ milk for $1 \mathrm{~h}$ at room temperature and were then washed 3 times in PBST. The membranes were then incubated with the cord blood serum at 1:200 dilution with the blocking solution at $4{ }^{\circ} \mathrm{C}$ overnight and washed 3 times. The membranes were then incubated with goat anti-human IgG-HRP-linked antibody (America, Santa Cruz Inc, 1:5 000) for $1 \mathrm{~h}$ at room temperature and washed 3 times.The protein levels were measured using a DAB Horseradish Peroxidase Color Development Kit.

\section{The protein P 6 was detected by indirect enzyme-linked immunosorbent assay}

After diluting the P6 sample with buffer solution, $100 \mu \mathrm{l}$ of sample was added into each well, and the sample was coated at $4{ }^{\circ} \mathrm{C}$ for $12 \mathrm{~h}$. Then, the plate was washed four times with PBST buffer. Then, $200 \mu \mathrm{l}$ of blocking solution was added to each well, and the plate was stored at $37{ }^{\circ} \mathrm{C}$ for $2 \mathrm{~h}$. The plate was washed with PBST buffer four times. Then, $100 \mu \mathrm{l}$ of serum diluted with a blocking solution (PBST solution containing 5\% BSA) was added. After being stored at $37^{\circ} \mathrm{C}$ for $1 \mathrm{~h}$, the plate was washed four times with PBST. Then, $100 \mu \mathrm{L}$ of goat antihuman antibody (America, Santa Cruz Inc) diluted with blocking solution was added and incubated at $37^{\circ} \mathrm{C}$ for $30 \mathrm{~min}$. The plate was washed as described above. Then, 
$100 \mu \mathrm{L}$ of TMB (America, KPL) was added to each well. The plate was stored in the dark for 5-15 min at RT. The optical density (OD) value at $450 \mathrm{~nm}$ (A450) was measured by microplate reader, and the OD value at $630 \mathrm{~nm}$ (A630) was used as a reference. The optimal conditions of serum dilution, antigen concentration and reaction time were established by performing a checkerboard titration. When the ratio of positive serum to negative serum A450s $(\mathrm{P} / \mathrm{N})$ was the best critical value, the coated antigen concentration was the best envelope concentration $[16,17]$.

\section{Data analysis}

Receiver operating characteristic (ROC) curve was drawn according to the OD value measured by the enzyme labelling method. The optimum critical value was determined by the Yoden index (Yoden index $=$ sensitivity + specificity -1 ). The sensitivity (Sensitivity $=[$ true positive cases/ (true positive cases + false negative cases) $] \times 100 \%$ ) and specificity $($ Specificity $=[$ true negative cases/(true negative cases + false positive cases) $] \times 100 \%$ ) of the new detection method were calculated according to the critical value. SPSS18 software was used for statistical analysis of the experimental data.

\section{Results}

P6 was obtained by prokaryotic expression

The recombinant plasmid with multiple epitopes (named P6T) was constructed by selecting the immunoactive sites on the two structural proteins of RV. The P6T plasmid was approximately 666 bp (Fig. 1). The plasmid was successfully constructed and identified by sequencing and double restriction enzyme digestion (Fig. 1). P6T was expressed in E. coli, and the product was named P6. SDS-PAGE showed that the molecular weight of the protein P6 was approximately $44 \mathrm{kDa}$ (Fig. 2). The expected fusion protein expressed encoded by just the pET-32a $(+)$ vector alone would be around $20.4 \mathrm{kDa}$. In addition, the expected fusion protein expressed encoded by the P6T plasmid would be around 23.29 kDa (GSGLQPRADMAAPPAPPQPPRAHGQHYGHHHHQLPFLGHDGHHGGTLRVGQHHRNASDVLPGHWLQGGW GCY NLSDWHQGTHVCHTKHMDFWCVEHDRPPPATPTPLTTAANATTAAGGGGSGGGGSGGGGSDPGDLVEYIMNYTGNQQSRWGLGSPNCHGPDWASPVCQRHSPDCSRLVGATPERPRLRLVDADDPLLRTAPGPGEVWVTPVIGSQARK). The results showed that the protein P6 could be expressed in E. coli. The protein was expressed as inclusion body at $0.283 \mathrm{mg} / \mathrm{mL}$.

Imidazole elution $(60 \mathrm{mM}, 150 \mathrm{mM}, 300 \mathrm{mM})$ was used for the purification of the target protein. The results of SDS-PAGE showed that P6 protein was the purest with
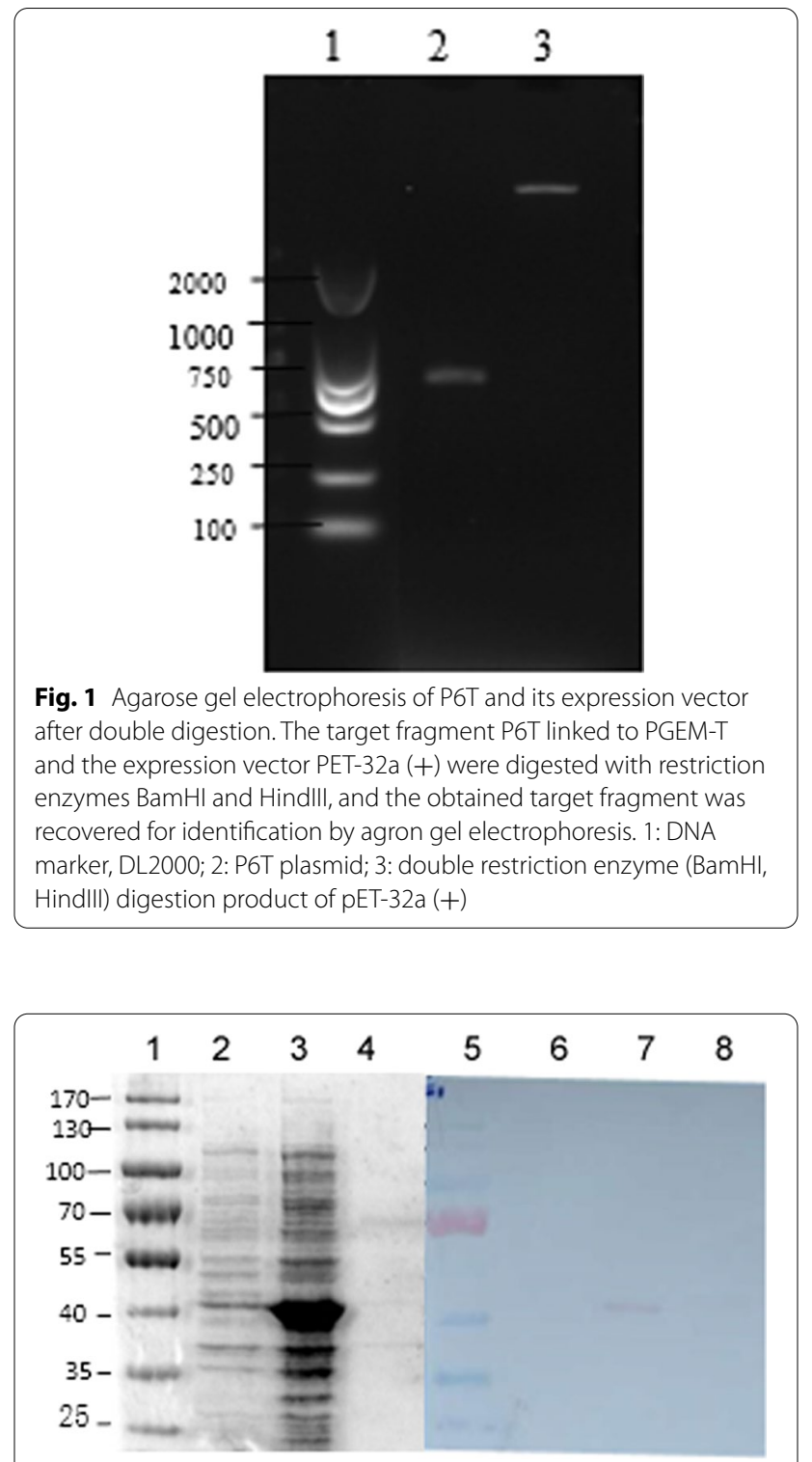

Fig. 2 Western blot identification of induced expression of P6 with human serum. The constructed recombinant expression plasmid was transformed into BL21(DE3), and then induced by IPTG to obtain P6 in the form of inclusion body. Western blot was used to identify P6 with positive and negative anti-RV serum respectively, and the desired band was obtained in the positive serum. 1: Marker; 2 . control (no IPTG induction); 3. expression product (IPTG induction: 2.5 h, 1 mM IPTG); 4. supernatant of expressed product; 5 . marker; 6. control; 7 . positive serum $+P 6 ; 8$. negative serum $+P 6$

$150 \mathrm{mM}$ imidazole concentration. It is more than $80 \%$ pure (Fig. 2).

\section{The protein $\mathrm{P} 6$ reacts with anti-RV serum}

The antigenicity of the protein P6 was identified by Western blotting. The results showed that the cord blood serum (RV-positive) as a first antibody and goat 
anti-human IgG-HRP as a second antibody showed a significant band at approximately $44 \mathrm{kDa}$. Moreover, RVnegative serum as a primary antibody showed no band (Fig. 2). No protein P6 was added, and no significant bands were observed with either RV-positive or RV-negative serum (Fig. 2). The results showed that the protein P6 could react specifically with RV-positive serum.

\section{P6 indirect enzyme-linked immunosorbent assay for identification of blood samples}

The optimal conditions of serum dilution, antigen concentration and reaction time were established. The purified P6 protein was used as antigen at an optimal concentration of $5 \mu \mathrm{g} / \mathrm{ML}$. The use of purified antigen allowed the testing of sera at a 1:50 dilution without nonspecific reaction. Ninety-four samples of umbilical cord blood (VirionSerion ELISA method) were selected to verify the accuracy of this method (Table 1). An ROC chart was drawn according to the OD value, and the Yoden index was used to determine the best cut off (cut off $=0.317$ ). According to the critical value (Fig. 3), the coincidence rate, specificity and sensitivity of the ELISA were $86.2 \%, 88.89 \%, 84.48 \%$ respectively.

Regarding the Chi-square test results, kappa $=0.715$ and $P<0.05$. The results showed that there was no significant difference between the P6 indirect ELISA and the known results.

\section{Discussion}

There are two types of rubella virus ELISA kits available on the market for testing IgM and IgG antibodies. When pregnant women are infected with RV but not infected in utero, the detection time of IgM antibody is short. When pregnant women are infected with rubella virus in utero, RV IgM antibody can be continuously detected before delivery [18]. Therefore, rubella virus IgM test is suitable for early infection and termination of pregnancy detection. The detection of RV IgG is suitable for the seroepidemiological investigation of RV. The monitoring of RV in China began in 1999 [19]. At present, ELISA is mainly used to investigate the evaluation of individual protective antibodies against RV and the investigation of antibody levels in the population. Meanwhile, the neutralization

Table 1 The coincidence rate of P6 indirect ELISA and VirionSerion detection

\begin{tabular}{lccc}
\hline P6 ELISA method & \multicolumn{2}{l}{ VirionSerion ELISA method } \\
\cline { 2 - 4 } & Positive & Negative & Total \\
\hline Positive & 49 & 9 & 58 \\
Negative & 4 & 32 & 36 \\
Total & 53 & 41 & 94 \\
\hline
\end{tabular}

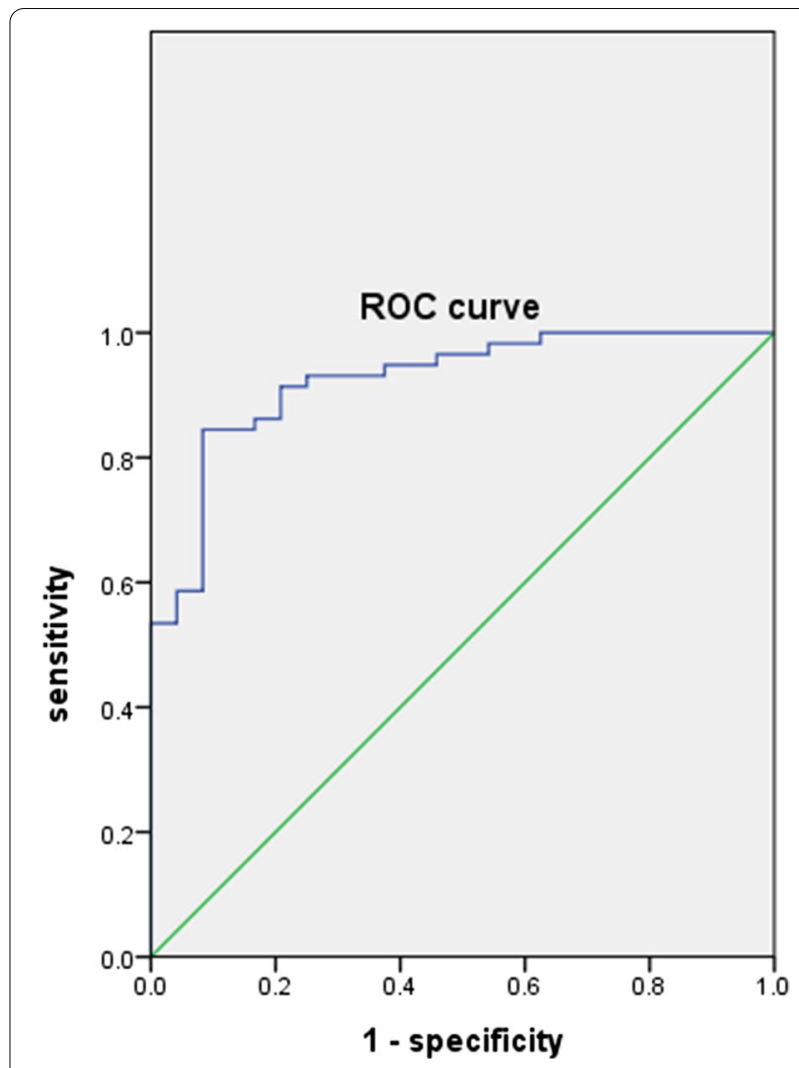

Fig. 3 ROC curve of 94 cord blood was detected by P6 indirect ELISA. The optimum critical value was determined by the Yoden index (Yoden index $=$ sensitivity + specificity -1$)$. Sensitivity $=[$ true positive cases/(true positive cases + false negative cases)] $\times 100 \%$. Specificity $=$ [true negative cases/(true negative cases + false positive cases) $] \times 100 \%$. The optimal critical value was 0.317 . According to the critical value, the coincidence rate, specificity and sensitivity of the ELISA were $86.2 \%, 88.89 \% \mathrm{~m} 84.48 \%$ respectively

test is used for auxiliary verification. Because RV is complex to operate and have the risk of infection. At present, the quality of rubella IgG kits produced in China are uneven and the imported kits are expensive [20,21]. Therefore, it is very important to establish a good rapid clinic serological detecting method for RV.

In this study, Escherichia coli BL21 (DE3) was selected as the expression system. Prokaryotic expression system is easy to survive, convenient to purchase and low cost. Its genomic information is simple and clear. The method is simple and efficient for the transformation of recombinant plasmid. When used to express foreign protein, the expression amount is high, and the expressed product is stable. Compared with prokaryotic expression system, Eukaryotic expression system has high cost, complex operation and low yield.

In this paper, the critical value of $\mathrm{RV}$-specific $\mathrm{IgG}$ was determined by the ROC curve method. At present, there are many methods to determine the critical value 
of ELISA, such as the standard curve method, mean plus minus standard deviation method, ROC curve method, response surface optimization method, and uniform design $[15,22,23]$. The ROC curve method is a widely used method to determine the critical value considering specificity and sensitivity [24-26]. The practicality of the proposed method was tested by qualitative analysis of serum data, so the ROC curve method was used to determine the critical value of the proposed method.

There may be some deficiencies in the establishment of the ELISA in the experiment. First, the optimization of ELISA experimental processes involves a number of conditions. Not all the conditions have been tried. Second, only the effective antigen sites of rubella virus E1 and E2 were expressed in this study. Within contrast to the whole virus, the other antigen sites were not expressed. Therefore, there was the possibility of missed detection. Finally, this experiment selected a limited number of serum samples. In order to evaluate the validity of established methods more rigorously, larger sample sizes are required for validation.

\section{Conclusions}

In conclusion, the recombinant protein P6 was expressed by a prokaryotic expression system. An indirect ELISA method for the detection of IgG antibody in serum was established by using P6. Although this method had some shortcomings, it had strong specificity. After optimization, it would be expected to provide a laboratory basis for the development of an RV detection kit with high specificity and sensitivity. The results provide a practical and effective plan for epidemiological surveys of RV in China.

\section{Abbreviations}

RV: Rubella virus; E. coli: Escherichia coli; LB: Luria-Bertani; OD: Optical density.

\section{Acknowledgements \\ The authors are very thankful to Dr.XU Wenbo, Professor of Institute for Viral Disease Control and Prevention, for his help to provide sam- ples for our research. We also gratefully acknowledge the help of Dr. CAO Lei, who has offered our valuable suggestions in the research.}

\section{Authors' contributions}

HRP and XWY designed and initiated the study. XWY and ZJN carried out the experiment. MCL,XX,XHT and YSM performed the statistical analysis. LL and $\mathrm{XWY}$ drafted the manuscript. MYH and $\mathrm{YH}$ revised the manuscript. All authors read and approved the final manuscript.

\section{Funding}

This work was supported by "Trinity" College Students Innovation and Entrepreneurship Cultivation Project of Inner Mongolia Medical University (SWYT2020023), the Research Project of the Inner Mongolia Natural Science Foundation Project (2019MS08009), "Youth Innovation Fund" project of Inner Mongolia Medical University (YKD2020QNCX061), Inner Mongolia health and family planning scientific research projects (201701047).

\section{Availability of data and materials}

The datasets used or analysed during the current study are available from the corresponding author on reasonable request.

\section{Declarations}

Ethics approval and consent to participate

Not applicable.

\section{Consent for publication}

Not applicable.

\section{Competing interests}

The authors have declared no competing interests.

\section{Author details}

${ }^{1}$ College of Basic Medicine, Inner Mongolia Medical University, Hohhot 010110, Inner Mongolia, China. ${ }^{2}$ The People's Hospital of Jiang County, Shanxi 043600, China. ${ }^{3}$ School of Life Sciences, Inner Mongolia University, Hohhot, China.

Received: 23 August 2021 Accepted: 31 January 2022

Published online: 23 February 2022

\section{References}

1. Banatvala JE, Brown DW. Rubella. Lancet. 2004;363:1127-37.

2. Best JM. Rubella. Semin Fetal Neonatal Med. 2007;12:182-92.

3. Lambert N, Strebel P, Orenstein W, Icenogle J, Poland GA. Rubella. Lancet. 2015;385:2297-307

4. Messedi E, Fki-Berrajah L, Gargouri S, Chouikha A, Chaari A, Bouaziz M, Jallouli H, Yahia AB, Hammami A, Triki H, Karray-Hakim H. Clinical epidemiological and molecular aspects of rubella outbreak with high number of neurological cases, Tunisia 2011-2012. J Clin Virol. 2014;61:248-54.

5. Ujiie M, Nabae K, Shobayashi T. Rubella outbreak in Japan. Lancet. 2014:383:1460-1.

6. Dimech W, Mulders MN. A 16-year review of seroprevalence studies on measles and rubella. Vaccine. 2016;34:4110-8.

7. Zhu Z, Cui A, Wang H, Zhang Y, Liu C, Wang C, Zhou S, Chen X, Zhang $Z$, Feng $D$, et al. Emergence and continuous evolution of genotype $1 E$ rubella viruses in China. J Clin Microbiol. 2012;50:353-63.

8. Schluter WW, Reef SE, Redd SC, Dykewicz CA. Changing epidemiology of congenital rubella syndrome in the United States. J Infect Dis. 1998; 178:636-41.

9. Reef SE, Redd SB, Abernathy E, Zimmerman L, Icenogle JP. The epidemiological profile of rubella and congenital rubella syndrome in the United States, 1998-2004: the evidence for absence of endemic transmission. Clin Infect Dis. 2006;43(Suppl 3):S126-132.

10. Zhu Z, Rivailler P, Abernathy E, Cui A, Zhang Y, Mao N, Xu S, Zhou S, Lei Y, Wang $Y$, et al. Evolutionary analysis of rubella viruses in mainland China during 2010-2012: endemic circulation of genotype 1E and introductions of genotype 2B. Sci Rep. 2015;5:7999.

11. Skrastina D, Petrovskis I, Petraityte R, Sominskaya I, Ose V, Lieknina I, Bogans J, Sasnauskas K, Pumpens P. Chimeric derivatives of hepatitis B virus core particles carrying major epitopes of the rubella virus E1 glycoprotein. Clin Vaccine Immunol. 2013;20:1719-28.

12. White SJ, Boldt KL, Holditch SJ, Poland GA, Jacobson RM. Measles, mumps, and rubella. Clin Obstet Gynecol. 2012;55:550-9.

13. Liu Y, Yu F, Huang H, Han J. Development of recombinant antigen array for simultaneous detection of viral antibodies. PLOS ONE. 2013;8:e73842.

14. Dimech W, Mulders MN. A review of testing used in seroprevalence studies on measles and rubella. Vaccine. 2016;34:4119-22.

15. Zhu Z, Abernathy E, Cui A, Zhang Y, Zhou S, Zhang Z, Wang C, Wang T, Ling $\mathrm{H}$, Zhao C, et al. Rubella virus genotypes in the People's Republic of China between 1979 and 2007: a shift in endemic viruses during the 2001 Rubella Epidemic. J Clin Microbiol. 2010;48:1775-81.

16. Petrova EK, Dmitrieva AA, Trifonova EA, Nikitin NA, Karpova OV. The key role of rubella virus glycoproteins in the formation of immune response, 
and perspectives on their use in the development of new recombinant vaccines. Vaccine. 2016;34:1006-11.

17. English Al. Global distribution of measles and rubella genotypes update. Releve Epidemiologique Hebdomadaire. 2006;81:474.

18. Pande M, Frazier ML. Epidemiology. Colorectal Cancer: Diagnosis and Clinical Management; 2014.

19. Zhu Z, Wen-Bo XU. Molecular epidemiological of rubella virus. Chin J Vaccines and Immunization 2007.

20. Yu T, Qu S, Zhang X, Sun N, Huang J. The quality analysis of national supervising sampling for rubella virus IgM diagnostic kits in 2014. Chin J Med Instrum

21. Hou LP, An LL, Zhang M, Sun DG, Ma X. Comparison of 7 kits for detection of rubella lgG antibodies. Chin J Family Plan. 2010;175:212-4.

22. Zhang Y, Xu S, Wang H, Zhu Z, Ji Y, Liu C, Zhang X, Sun L, Zhou J, Lu P, et al. Single endemic genotype of measles virus continuously circulating in China for at least 16 years. PLOS ONE. 2012;7:e34401.

23. Chen M, Zhang Y, Huang F, Wang H, Liu D, Li J, Rodewald L, Wu J, Deng Y, Xu W. Endemic and imported measles virus-associated outbreaks among adults, Beijing, China, 2013. Emerg Infect Dis. 2015;21:477-9.

24. Giessauf A, Letschka T, Walder G, Dierich MP, Wurzner R. A synthetic peptide ELISA for the screening of rubella virus neutralizing antibodies in order to ascertain immunity. J Immunol Methods. 2004;287:1-11.

25. Scholz C, Thirault L, Schaarschmidt P, Zarnt T, Faatz E, Engel AM, Upmeier $B$, Bollhagen R, Eckert B, Schmid FX. Chaperone-aided in vitro renaturation of an engineered $E 1$ envelope protein for detection of anti-Rubella virus IgG antibodies. Biochemistry. 2008;47:4276-87.

26. Mangala Prasad V, Willows SD, Fokine A, Battisti AJ, Sun S, Plevka P, Hobman TC, Rossmann MG. Rubella virus capsid protein structure and its role in virus assembly and infection. Proc Natl Acad Sci USA. 2013;110:20105-10.

\section{Publisher's Note}

Springer Nature remains neutral with regard to jurisdictional claims in published maps and institutional affiliations.

- fast, convenient online submission

- thorough peer review by experienced researchers in your field

- rapid publication on acceptance

- support for research data, including large and complex data types

- gold Open Access which fosters wider collaboration and increased citations

- maximum visibility for your research: over $100 \mathrm{M}$ website views per year

At BMC, research is always in progress.

Learn more biomedcentral.com/submissions 